tion demonstrates what is lacking and the root of the trouble lies outside the Department and at a higher level.

For the rest the book, lucid and authoritative, is admirably conceived. After setting forth first the constitution and functions of the Department as re-stated in the Act of 1956 and outlining the extent and magnitude of its existing activities, Sir Harry gives an excellent summary of the origin and development of the Department from 1915 to the present time. This account, which pays deserved tribute to those who played so large a part in getting the Department started and steering it safely through the early years, is supplemented in the appendix by lists of successive Lord Presidents of the Council, Chairman of the Advisory Council and Secretaries of the Department. A brief chapter on the organization and control of the Department follows, and there is one describing the Department's system of grants for postgraduate training and research.

In this chapter, as in that on the co-operative research associations, Sir Harry attempts to assess impartially the benefits to Britain which have flowed from these activities, and at the same time to indicate some of the implications and questions of policy which arise. Four chapters on the Department's own research establishment, apart from a brief concluding survey, complete the volume and these chapters cover the stations which have now been closed, or for which the responsibility has been transferred to other Departments or Research Councils. In his impressive picture of the benefits which the Nation draws from the activities of all these research establishments, it is curious, however, that Sir Harry makes no reference to work done, notably at the Road Research Station and the Building Research Station, on behalf of overseas territories. Some work for overseas is also done by the Pest Infestation Laboratory, now the responsibility of the Agricultural Research Council, and by the Tropical Products Institute for which the Department became responsible in 1959, and in assessing the significance of the work of the Department as a whole it should be recognized that the overseas territories benefit as well as Britain herself.

R. BRIGHTMAN

\section{TEXT-BOOK OF VIROLOGY}

\section{Wirusologia Ogolna}

Edited by Dr. E. Mikulaszek and Dr. W. Dobrzanski. Pp. 580. (Warszawa: Panstwowe Wydawnictwo Naukowe, 1960.) Cena zl. 70.

$\mathrm{N}$ the world literature there are relatively few text-books on general virology; this book is the first and only one on the subject written in Polish by Polish authors.

The editors are obviously in step with present-day trends in virology which, after a period of interest in practical application of the existing knowledge, is now entering a phase of very rapid theoretical advance due largely to general progress in all biological sciences and to the active interest in virology of scientists specializing in other biological disciplines.

A young and vigorously developing science like virology is often faced with divergences not only in observations but also in their interpretation; this makes adequate presentation in a text-book no easy matter. Fortunately, this problem seems to have been overcome in this book.
It is never easy to arrange for uniform presentation in a book written by numerous authors. In this instance it is clear from the references that not all the chapters were written at the same time; some are two or three years older than others, and this has made the problem even more difficult. Some chapters are rather reminiscent of monographs, while others-elaborated in masterly fashion-uphold the tradition of the high quality university text-books.

The book is evidently intended for science students and graduates who wish to become acquainted with virology or to broaden their knowledge of the subject. It attains its object on the whole, but suffers from the fact that much of it is based on the literature up to 1956 or 1957-only in some chapters are references from 1959 quoted-and that some important publications from the period summarized are not referred to.

These criticisms, however, do not alter the fact that the book is of great value in that it attempts to give a general conspectus of virology, and to integrate all our knowledge of viruses into one biological discipline. There is a chapter on "Viruses in Biocenotic Complexes" which 'enlivens' the whole subject, and also a chapter on "Plant Viruses" skilfully written in an introductory form; similar chap. ters on animal and bacterial viruses would have been very valuable.

The chapters are well planned, the illustrations are good and the discussion is lucid; there are numerous tables. The indexes are good. What is needed, besides what we have already noted, is further integration of the contents, uniformity of presentation and avoidance of repetition; a chapter outlining technical methods would be desirable. A new edition revised on these lines would be well worth while, and it would be such a good book that a translation into English would be of the greatest value.

\section{J. W. Czekalowski}

\section{VIBRATIONS AND WAVES}

\section{An Introduction to the Physics of Vibrations and Waves}

By Prof. Norman Feather. (Science and Mathematics Texts, No. 4.) Pp. viii + 330. (Edinburgh: At the University Press, 1961. Distributed by Thomas Nelson and Sons, Ltd.) 30s. net.

$\mathrm{W}$ ITH Mass, Length, and Time, Prof. Feather gave us a book which went quite deeply into the foundations of physics, and traced the historical emergence of the concepts; this was for the "beginning specialist" in physics, and the mathematical treatment was elementary. The present volume, based on lectures for second-year honours students who had worked through the previous course, deals with strings and rods and pipes, the propagation of plane waves in an infinite medium, water waves, interference and diffraction, and the wave-particle duality. The mathematics is appropriate to this more advanced level.

The author speaks in the preface of his "unorthodox" approach. This really means that he proceeds by a careful analysis of a number of particular cases, and has selected a limited field for detailed study. Thus, in Chapter 3 on coupled vibrations, he discusses the loaded string, Barton's pendulums, and two interesting experiments by Searle and Wilberforce, 